Ю. М. Колесник, М. О. Авраменко, С. А. Моргунцова, О. А. Рижов Запорізький державний медичний університет

\title{
ДОСВІД ВПРОВАДЖЕННЯ ОНЛАЙН-ТЕХНОЛОГІЙ У СИСТЕМУ ПІДГОТОВКИ ФАХІВЦІВ ГАЛУЗІ ЗНАНЬ 22 “ОХОРОНА ЗДОРОВ’ Я”
}

\author{
Y. M. Kolesnik, M. O. Avramenko, S. A. Morhuntsova, O. A. Ryzhov \\ Zaporizhzhia State Medical University

\section{THE EXPERIENCE OF INTRODUCING ONLINE TECHNOLOGIES} \\ INTO THE SYSTEM OF TRAINING SPECIALTIES IN THE FIELD OF \\ KNOWLEDGE 22 "HEALTH PROTECTION"
}

\begin{abstract}
Мета роботи - проаналізувати впровадження в навчальний процес ВМ(Ф)НЗ курсів за вибором за формою дистанційного навчання за технологією онлайн-курсів, які реалізовані на платформі edX, що розташована на віртуальному сервері хмари Azure.

Основна частина. У статті представлено досвід впровадження сучасних технологій у форматі on line в систему підготовки фахівців галузі знань 22 “Охорона здоров’я”. Автори розкривають послідовність організаційних кроків до вирішення завдання реалізації повного циклу технологій е-learning: від розробки онлайн-курсу до організації процесу самостійної роботи студентів з онлайн-сервісами. Розкриті основні складнощі імплементації інноваційних форм навчання до консервативної системи організації навчального процесу медичного університету, а саме: організація вільного вибору дисциплін при підготовці фахівців, забезпечення якісної організації самостійної роботи студента, запровадження нових методів підготовки до ліцензійного іспиту “Крок”, та запропоновані шляхи їх вирішення.

Висновок. Імплементація технологій е-learning у систему додипломної освіти медичного університету курсів у форматі курсів за вибором дозволяє надати студентам реальний вибір курсів, а також відображати в контенті цих курсів найсучасніші досягнення науково-практичного напрямку, привносить елементи інтерактивності до процесу навчання, а також створює умови для дистанційного моніторингу навчальної активності студентів викладачами.
\end{abstract}

Ключові слова: медична освіта; дистанційне навчання; онлайн-курси; LMS edX; хмарні сервіси IT.

The aim of the work - to analyze the introduction into the educational process of Medical (Pharmaceutical) Institutions of Higher Education of elective courses in the form of distance learning based on the online course technology, implemented on the edX platform located on the Azure cloud virtual server.

The main body. The article presents the experience of introducing modern online technologies into the system of training of specialists in the field of knowledge 22 "PUBLIC HEALTH". The authors show the sequence of organizational steps to be taken, to implement the full cycle of e-learning technologies: from elaborating an online course to organizing the process of students' self-study with online services. We found the main difficulties of implementing the innovative forms of education into the conservative system in which educational process is organized at medical universities: organization of free choice of disciplines in the training of specialists; ensuring quality organization of students' self-study; introduction of new methods of training for the KROK licensed exam, and ways to resolve them were suggested.

Conclusion. Implementation of e-learning technologies in the system of graduate education at a medical university in the format of elective courses makes it possible to provide students with real choice of courses as well as to reflect the most advanced scientific and practical achievements in the content of these courses, brings elements of interactivity into the learning process, and also creates conditions for remote monitoring of students' academic activity by teachers.

Key words: medical education; distance learning; online courses; LMS edX; IT cloud services.

Вступ. Закони України “Про вищу освіту”, “Про освіту”, інші законодавчі акти та національні програми містять чітко визначені поняття, плани та заходи щодо недопущення зниження якості освіти, неприпустимості застосування застарілих методів навчання.
Науково-педагогічний колектив Запорізького державного медичного університету при підготовці фахівців галузі знань 22 “Охорона здоров’я”, забезпечуючи виконання вимог нормативно-правової бази, прагне бути осередком прогресу, закладом системно високої якості освітніх послуг. Запро-

\footnotetext{
(С) Ю. М. Колесник, М. О. Авраменко, С. А. Моргунцова, О. А. Рижов
} 
вадження освітніх інновацій в університеті має постійний характер. Колектив має беззаперечні та суттєві здобутки, надбання, запроваджено ряд новітніх технологій, які до цього не використовувалися у вищих медичних навчальних закладах у даному вигляді, формах чи масштабі.

При цьому слід враховувати, що вища медична освіта є детально вибудованою і структурованою системою, прийняття рішень щодо нововведень і запровадження змін повинно мати обгрунтовані аргументи до початку введення інновацій.

Проаналізувавши діючу систему підготовки фахівців галузі знань 22 “Охорона здоров’я”, було визначено доцільним запровадження змін у проекції на майбутній результат. Колектив університету прийняв рішення про запровадження нових форм та технологій навчання до існуючих в університеті.

Вважаємо, що на даний час в організації освітнього процесу підготовки фахівців галузі знань 22 “Охорона здоров'я” існують 3 розділи, організація яких підлягає негайному вирішенню, а новітні освітні технології $є$ вдалими інструментами до даного процесу. Вказаними питаннями є:

- реалізація п. 15 ст. 62 Закону України “Про вищу освіту” [1];

- забезпечення якісної організації самостійної роботи студента;

- запровадження нових методів підготовки до ліцензійного іспиту “Крок”.

Мета роботи - аналіз кроків впровадження в навчальний процес ВМ(Ф) Н3 курсів за вибором за формою дистанційного навчання за технологією онлайн-курсів, які реалізовані на платформі edX [2], що розташована на віртуальному сервері хмари Azure.

Основна частина. Колектив університету, опрацювавши протягом 2015-2016 н. р. існуючий вітчизняний та світовий досвід, дійшов висновку, що ми маємо перспективи щодо запровадження власних інновацій. Організація вільного вибору дисциплін при підготовці фахівців галузі знань 22 “Охорона здоров’я” неодноразово обговорювалася на засіданнях та нарадах представників закладів вищої освіти та МОЗ України. Згідно з Листом МО3 України від 29.06.2016 року № 23-01-9/255, Рішенням XIII Всеукраїнської науково-практичної конференції з міжнародною участю “Актуальні питання якості медичної освіти” 12-13 травня 2016 року, зазначено: враховуючи особливості галузі та специфіку професійної діяльності фахівців про- фесійної кваліфікації “Лікар”, “Лікар-стоматолог”, реалізація п. 15 ст. 62 Закону України “Про вищу освіту” в повному обсязі є неможливою.

Колектив університету запропонував шляхи реалізації ст. 62 Закону України “Про вищу освіту”. ЗДМУ першим серед закладів вищої медичної освіти України запровадив у 2016-2017н. р. вивчення дисциплін вільного вибору студентів за допомогою новітніх інформаційних технологій онлайн-курсів [3]. Але мався на увазі не пошук в електронних ресурсах Інтернету онлайн-курсів, а створення власних. Адже, по-перше, онлайн-курси $€$ новою формою навчання (позитивно оціненою освітньою спільнотою та взятою до активного використання) і потрібних нам курсів не існувало взагалі; по-друге, саме викладачі університету визначили “форму” цих курсів - від дизайну до видів контролю, сформувавши цілісну авторську модель онлайн-курсів ЗДМУ. Відповідно до розробленої концепції корпоративних знань, онлайн-курси, які $€$ інтелектуальним продуктом, створеним професорсько-викладацьким складом, $\epsilon$ не тільки засобом для навчання студента, а $є$ витвором, який фіксує сучасний досвід відповідного наукового напрямку для забезпечення соціальних потреб суспільства. Створення онлайн-курсу дає можливість зафіксувати точку опори для розвитку студента. Треба відзначити, що матеріал, представлений в онлайн-курсі, має найкоротшу траєкторію доставки навчальної інформації до студента, тому є найліпшою формою для організації навчання саме курсів за вибором, які повинні відображати сучасні напрямки розвитку медицини та фармації.

Масштабування впровадження інноваційних сучасних технологій навчання на всі (61) кафедри університету потребує наявності відповідних складових педагогічної системи, таких, як: наявність чіткої програми розробки та імплементації в навчальний процес; наявність потужної інфраструктури для забезпечення доступу до цифрових ресурсів; наявність відповідного рівня IT-компетенцій у викладачів, що необхідно для розробки та супроводу онлайн-курсів та навчання; наявність відповідного рівня IT-компетенцій та технічного забезпечення (комп’ютерні аудиторії вільного доступу або персональні мобільні пристрої) у студентів. Згідно $з$ Концепцією розвитку ЗДМУ, Концепцією інформатизації ЗДМУ $[4,5]$, розроблено перспективний план запровадження онлайн-курсів. Тому на даний час ми можемо говорити про застосування даної 
методики навчання для вирішення інших питань, про що буде зазначено нижче.

Потужна матеріальна база університету повною мірою дозволяє реалізувати найсміливіші сучасні освітні проекти: усі кафедри університету (61) та структурні підрозділи забезпечені необхідними і часто унікальними приладами, обладнанням і комп'ютерними програмами. Сьогодні активно використовується і продовжує модернізуватися єдиний інформаційний простір університету. Концепція використання персональних мобільних приладів студентів для роботи з онлайн-сервісами повинна бути забезпечена умовами для їх використання. На території університетського містечка діють 42 потужних Wi-Fi-роутери, які забезпечують студентам і співробітникам безкоштовний доступ до мережі “ІІнтернет”, можливість роботи з електронними ресурсами університету. Розроблено пілотний проект для встановлення на території читального залу наукової бібліотеки обладнання, яке дозволить одночасно працювати 50-80 студентам із високошвидкісною Wi-Fi-мережею. Вирішення цього складного технічного завдання дозволяє залучити до навчального процесу технологію інтерактивних лекцій з миттєвим зворотним зв’ язком зі студентами.

Для розширення інтерактивності студентів із викладачами університетом створено додатково три центри, це телемедичний центр в університетський клініці ЗДМУ, медійний центр на кафедрі дитячих хвороб ФПО і на кафедрі акушерства, гінекології та репродуктивної медицини ФПО. Освітній простір університету розширився далеко за межі кампуса і клінічних баз, розташованих у межах міста. Сформована корпоративна освітня мережа ЗДМУ включає в себе два рівні: рівень обласної мережі і регіональний.

На підтримання та оновлення матеріальної бази університету щорічно витрачаються значні кошти. Всі запити колективу вважаються першочерговими до виконання, оскільки є чітке розуміння - сучасне оснащення дає змогу ефективно та у стислі терміни реалізувати інноваційні освітні проекти.

Програма ректорату по розвитку інфраструктури ЗДМУ дозволила побудувати інтернет-середовище кампуса для впровадження нових технологій навчання. Наступним кроком стала розробка програми розвитку нових IT-компетенцій у викладачів та студентів. Для викладачів кафедр була запропонована концепція: “Сучасний рівень кваліфікації викладача університету потребує кваліфікації для підготовки та викладення навчально-методичного матеріалу в онлайн-курсі, оскільки у минулому викладач повинен був вміти підготувати презентацію для лекції”. На підготовчому етапі було визначено, що для успішної реалізації даного питання першочерговими завданнями є організація і навчання нової технології науково-педагогічного складу університету та формування моделі взаємодії структурних підрозділів.

Протягом 2016-2017 н. р. кафедрою медичної та фармацевтичної інформатики і новітніх технологій ЗДМУ проведено три цикли підвищення кваліфікації викладачів університету. Навчання здійснювалося згідно з затвердженими програмами курсів і передбачало опанування технології, методики розробки онлайн-курсів на платформі edX. Підсумковим завданням слухачеві до завершення циклу було створення кафедрального курсу. Сертифікати про успішне навчання отримали понад 120 викладачів. Досвід розробки онлайн-курсів узагальнено на навчальнометодичній конференції ЗДМУ у 2017 році “Технології дистанційного навчання у медичній освіті: від віртуальності до реальності”. Інновація отримала визнання колег. Згідно з рішенням XIV Всеукраїнської науково-практичної конференції з міжнародною участю “Сучасні підходи до вищої медичної освіти в Україні” (м. Тернопіль, 18-19 травня 2017 року), закладам вищої медичної освіти рекомендовано активізувати запровадження онлайн-курсів, створених на платформі edX, та інші інновації, що використовуються у ЗДМУ. Учасники конференції “Роль освіти у впровадженні цілей сталого розвитку до 2030 року в Україні” (м. Київ, 7 грудня 2017 року) - представники закладів вищої освіти, підпорядкованих МОН України, також схвально і зацікавлено сприйняли доповідь представників ЗДМУ щодо використання інноваційних технологій в освітньому процесі.

3 метою формування необхідних практичних навичок для роботи в онлайн-середовищі для студентів 1 курсу, за наказом ректора, було розроблено та проведено спеціалізований навчальний курс, а також адаптовано навчальну програму на 2 курсі лікувального факультету навчальної дисципліни “Медична інформатика”, як дисципліни, яка забезпечує формування інформаційно-комунікаційних знань та вмінь. Для проведення занять на 1 курсі було розроблено робочу програму, до якої увійшли лекції (2 години) та практичні роботи (8 годин). Визначено мету курсу формування готовності студентів 1 курсу до дистанційного навчання на базі платформи edX. 
За результатами першого етапу запровадження онлайн-курсів було проведено незалежне анкетування студентів. Його результати свідчать про повне сприйняття студентською спільнотою нової технології навчання, їхньої готовності до індивідуального вибору дисципліни у форматі курсу за вибором та відповідальності щодо організації власної позааудиторної роботи. Студентам пропонується повний перелік курсів за вибором, близько 100 з них обираються для вивчення уже другий рік поспіль.

Використання сучасних інтернет- та хмарних сервісів дозволяє організувати самостійну роботу студента (СРС) на нових принципах, зробити її інтерактивною та контрольованою, використовуючи засоби дистанційного моніторингу навчальної діяльності (активності). Обсяг даного виду діяльності студента на даний час становить 50-60 \% від загального навантаження і різниться залежно від спеціальності. Питання ефективної та якісної організації СРС не потребує додаткової актуалізації та є беззаперечним і позиціонується до першочергових до вирішення. Одним із видів забезпечення самостійної роботи студента у ЗДМУ є використання системи онлайн-курсів. Відповідно до спільного Рішення Конференції трудового колективу та Вченої ради ЗДМУ, з 01.09.2017 року розпочато заходи з організації СРС у форматі онлайн-курсу. Даний вид для викладачів ЗДМУ не є надновим, тому що вже запроваджений з 01.03.2017 року на факультеті післядипломної освіти - для організації самостійної роботи лікарів-інтернів, провізорів-інтернів.

На даний час в університеті розроблено більше 200 онлайн-курсів із СРС. За їх допомогою студент може дистанційно, через Інтернет, ознайомитися $з$ навчальним матеріалом, представленим у вигляді різнотипних інформаційних ресурсів (текст, відео, анімація, презентація, електронний посібник та ін.), виконати завдання та відправити його на перевірку, пройти електронне тестування. Викладач має можливість самостійно створювати EOP і проводити навчання на відстані, надсилати повідомлення студентам, розподіляти, збирати та перевіряти завдання, вести електронні журнали обліку оцінок та відвідування, налаштовувати різноманітні ресурси курсу.

Якість онлайн-курсів визначено нами як пріоритетне питання. Тому, з перших етапів роботи 3 онлайн-курсами, створювалася та запроваджувалася система контролю якості. 3 метою своєчасного, об’єктивного аналізу та затвердження онлайн-курсів було створено комісію з представників ректора- ту та кафедр університету. За підсумками роботи комісії, готувалися експертні висновки та пропозиції. За пропозицією комісії, серед кафедр університету було проведено конкурс “Найкращий онлайн-курс”. Переможці були премійовані за номінаціями "Найкращий педагогічний дизайн онлайн-курсу”, "Найкращий інтерактивний дизайн онлайн-курсу”, “Найкращий технологічний дизайн онлайн-курсу”.

Перевіркою правильності вибраного напрямку реструктуризації навчального процесу та застосування сучасних технологій е-педагогіки (e-learning) стало рішення розробки інтегрованого міжкафедрального онлайн-курсу для підготовки до ліцензійного іспиту “Крок”. 3 метою забезпечення якісної підготовки студентів університету до складання ліцензійного іспиту “Крок 1”, “ Крок Б” вперше розпочато заходи зі створення та запровадження онлайн-курсів для підготовки студентів до ліцензійного іспиту “ Крок 1”, “ Крок Б”.

Вивчення даного онлайн-курсу вважається складовою виконання індивідуального плану студента ЗДМУ та умовою допуску до ліцензійного іспиту “ Крок 1”, “ Крок Б”. Онлайн-курси створюються для всіх категорій студентів (вітчизняні, іноземні, денна та заочна форми навчання, дублюються за мовою викладання дисциплін).

На даний час ми маємо перші результати вивчення онлайн-курсу в осінньому семестрі студентами спеціальності “Стоматологія”. За звітами деканатів, всі студенти успішно пройшли навчання та склали залік. Як результат - студенти ЗДМУ спеціальності “Стоматологія” посіли друге місце у загальному рейтингу 20 ВН3, які брали участь у тестуванні 20.02.2018 року. За даними експрес-аналізу результатів складання студентами громадянами України субтесту з іноземної мови професійного спрямування ліцензійного іспиту “Крок 1. Стоматологія”, наданого ДО “Центр тестування при МОЗ України”, 16 студентів ЗДМУ (9,1 \%) ввійшли до 10 \% студентів, які показали найвищі результати по країні.

Станом на 01.01.2018 року науково-педагогічний колектив ЗДМУ розробив та запроваджує 328 власних оригінальних онлайн-курсів. Дана технологія знайшла схвалення серед викладачів університету, як наслідок - поширення на інші види організації освітнього процесу. Так, за допомогою онлайнкурсів організовано вивчення іноземної мови для студентів та української мови для викладачів, які претендують на роботу в університеті.

Висновки. Імплементація технологій e-learning y систему додипломної освіти медичного універси- 
тету курсів у форматі курсів за вибором дозволяє надати студентам реальний вибір курсів, а також відображати в контенті цих курсів найсучасніші досягнення науково-практичного напрямку. Впровадження в навчальний процес онлайн-курсів для самостійної роботи привносить елементи інтерактивності до процесу навчання, а також створює умови для дистанційного моніторингу навчальної активності студентів викладачами.

Розробка онлайн-курсів на кожній кафедрі університету закладає фундамент формування кор-

\section{Список літератури}

1. Про вищу освіту : Закон України від 01.07.14 № 1556 -VII.

2. Gilbert M. A. edX E-Learning Course Development / Matthew A. Gilbert. - Birmingham B3 2PB, UK: Packt Publishing; 2015.

3. Стратегія впровадження курсів за вибором на базі технології онлайн-курсів на платформі edX / Ю. М. Колесник, М. О. Авраменко, С. А. Моргунцова, О. А. Рижов // Медична освіта. - 2017. - № 3. - С. 75-79.

\section{References}

1. Zakon Ukrainy "Pro vyshchu osvitu" vid 01.07.14 №1556-VII [Law of Ukraine “On Higher Education” of 01.07.14 No1556-VII]. [in Ukrainian].

2. Gilbert, M.A. (2015). edX E-Learning Course Development. Birmingham B3 2PB, UK: Packt Publishing.

3. Kolesnyk, Yu.M., Avramenko, M.O., Morhuntsova, S.A., \& Ryzhov, O.A. (2017). Stratehiia vprovadzhennia kursiv za vyborom na bazi tekhnolohii onlain kursiv na platformi edX [Strategy of implementing elective courses based on the online course technology on the edX]. Medychna osvita Medical Education, 3 [in Ukrainian].

4. Kolesnyk, Yu.M., \& Ryzhov, O.A. (2017). Kontseptsiia rozvytku dystantsiinoho navchannia u Zaporizkomu derzhavnomu medychnomu universyteti [Concept of development of distance learning at Zaporizhzhia State Medical University]. Aktualni pytannia farmatsevtychnoi ta medychnoi nauky ta praktyky. Zbirnyk naukovykh statei поративної бази знань університету, яка динамічно відображає сучасні тенденції розвитку науково-практичних напрямків медицини та фармації і створює умови для оптимізації траєкторії доставки навчального матеріалу до студента.

Підвищення рівня IT-компетенцій викладачів та студентів дозволяє ставити завдання розробки підходів до персоніфікації навчання. Візуалізація досягнень студента в персональному портфоліо може стати вагомим фактором мотивації студента до успішного навчання.

4. Колесник Ю. М. Концепція розвитку дистанційного навчання у Запорізькому державному медичному університеті / Ю. М. Колесник, О. А. Рижов // Актуальні питання фармацевтичної та медичної науки та практики. Збірник наукових статей. Випуск XVIII. - Запоріжжя : Вид-во ЗДМУ, 2007. - С. 11-21.

5. Колесник Ю. М. Концепція інформатизації медичних навчальних закладів / Ю. М. Колесник, О. А. Рижов // Актуальні питання фармацевтичної і медичної науки та практики. - 2013. - № 3. - С. 1-2.

- Current Issues of Pharmaceutical and Medical Science and Practice. Collection of Scientific Articles. Zaporizhzhia: Vyd-vo ZDMU [in Ukrainian].

5. Kolesnyk, Yu.M., \& Ryzhov, O.A. (2013). Kontseptsiia informatyzatsii medychnykh navchalnykh zakladiv [Concept of informatization of medical educational institutions]. Aktualni pytannia farmatsevtychnoi i medychnoi nauky ta praktyky: Dodatok / Tezy dopovidei Vseukrainskoi naukovo-metodychnoi videokonferentsii z mizhnarodnoiu uchastiu "Aktualni pytannia dystantsiinoi osvity ta telemedytsyny 2013” 10-11 zhovtnia 2013 r. - Current Issues of Pharmaceutical and Medical Science and Practice: Appendix/Abstracts of the All-Ukrainian Scientific and Methodical Videoconference with International Participation "Current issues of Distance Education and Telemedicine 2013” October 10-11, 2013, 3 (1-2) [in Ukrainian]. 